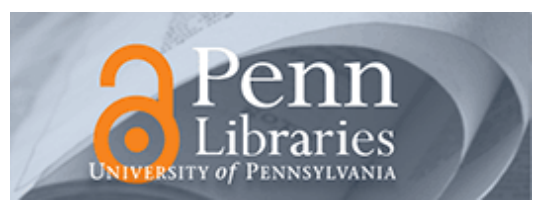

Manuscript Studies

\title{
A New Look at "Didacus" in a Late Twelfth-Century Manuscript from Santa María de Benevívere (Free Library of Philadelphia, Lewis E 22)
}

Matthew J. Westerby

CASVA, National Gallery of Art, m.westerby@gmail.com

Follow this and additional works at: https://repository.upenn.edu/mss_sims

Part of the European History Commons, and the Medieval Studies Commons

\section{Recommended Citation}

Westerby, Matthew J. (2021) "A New Look at "Didacus" in a Late Twelfth-Century Manuscript from Santa María de Benevívere (Free Library of Philadelphia, Lewis E 22)," Manuscript Studies: Vol. 5 : Iss. 2 , Article 5.

Available at: https://repository.upenn.edu/mss_sims/vol5/iss2/5

This paper is posted at ScholarlyCommons. https://repository.upenn.edu/mss_sims/vol5/iss2/5

For more information, please contact repository@pobox.upenn.edu. 


\title{
A New Look at "Didacus" in a Late Twelfth-Century Manuscript from Santa María de Benevívere (Free Library of Philadelphia, Lewis E 22)
}

\author{
Abstract \\ The manuscript Lewis E 22 at the Free Library of Philadelphia has an uncommonly complete provenance. \\ Written in the late twelfth century at Santa María de Benevívere in the Tierra de Campos of Palencia, \\ Spain, an ex libris inscription on the last lines of the final folio records its origin, with an enigmatic \\ addition by a later hand with the name "Didacus." Following the exclaustration of Benevívere in the \\ nineteenth century, the manuscript passed through a series of collections in England and Canada before \\ it arrived in the United States with John Frederick Lewis, including those of William Braggeand George \\ Dunn. Furnishing new evidence for its provenance and contextualizing its creation at Benevívere, this \\ paper offers a new interpretation of the Didacus inscription as a memorial to the monastery's founder, \\ Diego Martínez de Villamayor (d. 5 November 1176).
}

\section{Keywords}

Free Library of Philadelphia, Benevívere, Diego Martínez de Villamayor, Vita didaci, Bernard Quaritch, William Bragge, Colophon, Provenance, Didacus, Manuscript studies 


\section{MANUSCRIPT STUDIES}

A Journal of the Schoenberg Institute for Manuscript Studies

VOLUME 5, NUMBER 2

(Fall 2020)

Manuscript Studies (ISSN 2381-5329) is published semiannually

by the University of Pennsylvania Press

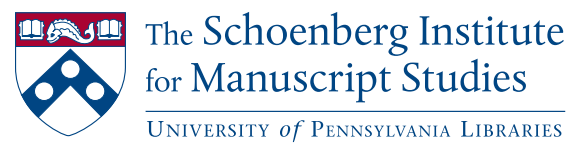




\title{
MANUSCRIPT STUDIES
}

V O L U M 5, N U M B R 2

(Fall 2020)

ISSN 2381-5329

\begin{abstract}
Copyright (c) 2020 University of Pennsylvania Libraries and University of Pennsylvania Press. All rights reserved.

Published by the University of Pennsylvania Press, 3905 Spruce Street, Philadelphia, PA 19104.
\end{abstract}

Printed in the U.S.A. on acid-free paper.

Manuscript Studies brings together scholarship from around the world and across disciplines related to the study of premodern manuscript books and documents, with a special emphasis on the role of digital technologies in advancing manuscript research. Articles for submission should be prepared according to the Chicago Manual of Style, $16^{\text {th }}$ edition, and follow the style guidelines found at http://mss.pennpress.org.

None of the contents of this journal may be reproduced without prior written consent of the University of Pennsylvania Press. Authorization to photocopy is granted by the University of Pennsylvania Press for libraries or other users registered with Copyright Clearance Center (CCC) Transaction Reporting Service, provided that all required fees are verified with CCC and paid directly to CCC, 222 Rosewood Drive, Danvers, MA 01923. This consent does not extend to other kinds of copying for general distribution, for advertising or promotional purposes, for creating new collective works, for database retrieval, or for resale.

2020 SUBSCRIPTION INFORMATION:

Single issues: $\$ 30$

Print and online subscriptions: Individuals: \$40; Institutions: \$94; Full-time Students: \$30 International subscribers, please add $\$ 19$ per year for shipping.

Online-only subscriptions: Individuals: $\$ 32$; Institutions: $\$ 82$

Please direct all subscription orders, inquiries, requests for single issues, address changes, and other business communications to Penn Press Journals, 3905 Spruce Street, Philadelphia, PA 19104. Phone: 215-573-1295. Fax: 215-746-3636. Email: journals@pobox.upenn.edu. Prepayment is required. Orders may be charged to MasterCard, Visa, and American Express credit cards. Checks and money orders should be made payable to "University of Pennsylvania Press" and sent to the address printed directly above.

One-year subscriptions are valid January 1 through December 31 . Subscriptions received after October 31 in any year become effective the following January 1. Subscribers joining midyear receive immediately copies of all issues of Manuscript Studies already in print for that year.

Postmaster: send address changes to Penn Press Journals, 3905 Spruce Street, Philadelphia, PA 19104.

Visit Manuscript Studies on the web at mss.pennpress.org. 


\title{
A New Look at "Didacus" in a Late Twelfth-Century Manuscript from Santa María de Benevívere (Free Library of Philadelphia, Lewis E 22)
}

\author{
Matthew J. Westerby \\ CASVA, National Gallery of Art
}

F EW Medieval European manuscripts in American collections are documented with a complete chain of ownership from their date of creation to the present day. Written in the late twelfth century at Santa María de Benevívere in the Tierra de Campos of Palencia, Spain, the manuscript Lewis E 22 at the Free Library of Philadelphia has a relatively complete provenance. An ex libris inscription on the last lines of the final folio records its origin at Benevívere (fig. 1). ${ }^{1}$ Furnishing new evidence for its provenance and contextualizing its creation at Benevívere, I offer here one possible interpretation for a scribal addition with the name "Didacus,"

\footnotetext{
A draft of this paper was presented in 2019 at the 54th International Congress on Medieval Studies in Kalamazoo, MI, as "Scriptor or Aedificator?: A New Look at a Twelfth-Century Manuscript (Free Library of Philadelphia, Lewis E 22) and the Monumental Sundial of Santa María de Benevívere.” I am grateful to Dot Porter, Lynn Ransom, and SIMS for organizing and sponsoring this session and to the audience for their questions and suggestions. I am also grateful to Caitlin Goodman, Joseph Shemtov, and Allison Freyermuth at the Free Library of Philadelphia and to the Manuscript Studies editors for their comments and suggestions.

1 Fol. 181v: "Hec est liber s(an)c(t)e marie de benevivere qui abstule / rit anathema sit, amen, am(en), amen.”
} 


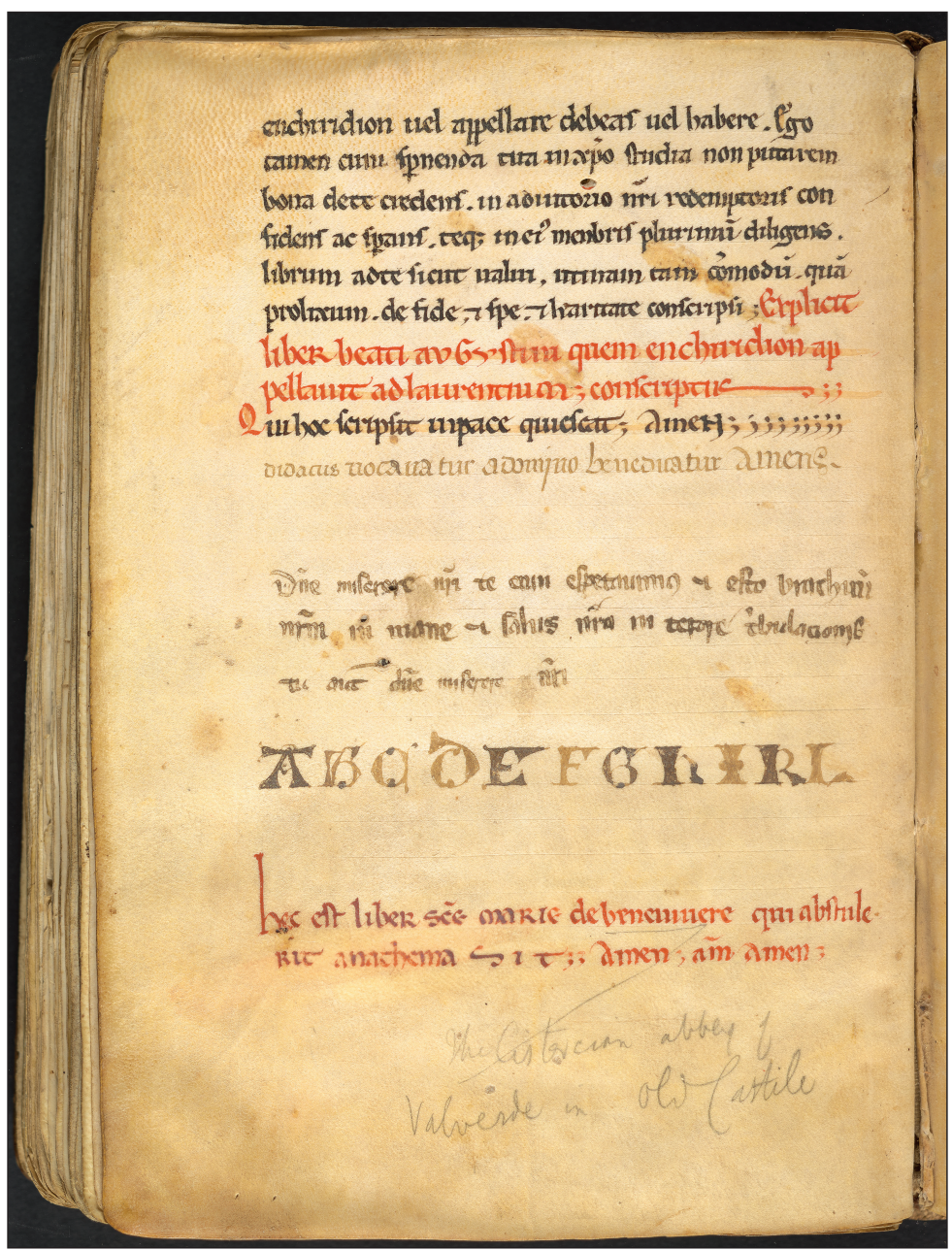

FIGURE 1. Philadelphia, Free Library of Philadelphia, Lewis E 22, fol. 181v.

which I suggest can be read as a memorial to the monastery's fabled founder, Diego Martínez de Villamayor (d. 5 November 1176). Recently photographed and catalogued as part of the Bibliotheca Pbiladelphiensis project, a digital avatar of the manuscript is now available through the BiblioPhilly interface. ${ }^{2}$

2 The BiblioPhilly website can be found at bibliophilly.library.upenn.edu. 


\section{Interrogating "Scripsit"}

The codex Lewis E 22 comprises two main text units, the first a commentary on the fifteen Gradual Psalms (Vulgate Psalms 119-133, fols. 1-132v) and the second a handbook on Christian piety called the Enchiridion (fols. $132 \mathrm{v}-181 \mathrm{v}){ }^{3}$ Both texts are attributed to Saint Augustine of Hippo (354-420 $\mathrm{CE}$ ) in the explicits on folios $132 \mathrm{v}$ and $181 \mathrm{v}$. Notes indicating where the rubrics were to be placed are written vertical to the page in the margins, visible just outside the remaining pricking marks. Small initials point to where blue and red initials were later to be added, in some cases never finished. These elements are valuable evidence of the practice of book production in the twelfth century from an understudied monastic scriptorium. ${ }^{4}$ Traces of the volume's past readers are also interspersed throughout the manuscript in the form of annotations, corrections, erasures, and small puddles of wax. Other scribal additions are found on the final folio and fly leaves, including two alphabets and prayers written in the fifteenth century. Inside the front cover of its binding are bookplates and inscriptions added by later owners, including two bookplates used by George Dunn (1864-1912) and one used by John Frederick Lewis (1882-1932). ${ }^{5}$ Worming through the boards is consistent with the opening parchment leaves, probably dating to the late twelfth century.

Short colophons on folios 132v and 181v state "Qui hoc scripsit in pace quiescat" ("may the scribe rest in peace"), both written by the same hand as the rubrics and the main texts. As the copyist (the "qui hoc scripsit"), the scribe chose to remain anonymous yet expressed a wish ("in pace quiescat")

3 Descriptions of Lewis E 22 are published in Edwin Wolf, A Descriptive Catalogue of the John Frederick Lewis Collection of European Manuscripts in the Free Library of Philadelphia (Philadelphia, 1937), no. 22, and on the BiblioPhilly website.

4 Along these lines, the binding and rare quire tackets in Lewis E 22 have been studied by Michael Gullick, "From Scribe to Binder: Quire Tackets in Twelfth Century European Manuscripts," in Roger Powell: The Compleat Binder, ed. John Sharpe (Turnhout: Brepols, 2006), 240-59.

5 I am grateful to William Stoneman for identifying the bookplate on the left side of the front board with a rampant fox and three stars as one used by George Dunn in his early acquisitions. This bookplate was previously unidentified. 
that associates salvation with scribal labor. A dedication was added by a later hand below the colophon on the final folio 181v (fig. 1), stating, "Didacus vocavatur a domino benedicatur" ("He was called Didacus, may he be blessed by the lord"). Like qui boc scripsit, the formula pairing vocabatur with benedicatur is common to scribal colophons in Iberian manuscripts across the Middle Ages, suggesting this might be a posthumous identification of the scribe who copied the text, and the inscription has been interpreted this way since the late nineteenth century. ${ }^{6}$

Placed within the early history of Benevívere, where the manuscript was copied and bound, the Didacus inscription perhaps takes on a different meaning tied more to the foundation of the monastery than to the hand of the scribe. Didacus, or Diego, was the name of the monastery's founder or aedificator, Diego Martínez de Villamayor (d. 5 November 1176 CE). Diego founded Benevívere in 1169 after occupying positions of power under three kings of Castile. His life is dramatized in 758 verses in the Vita Didaci, or Poema de Benevívere, which survives in a single manuscript today in Madrid, Archivo Histórico Nacional, MS 927 B, which also contains a monastic customary with rare evidence for when and where book production was permitted. ${ }^{7}$ The Vita Didaci was studied in a 2008 monograph by Estrella Pérez, which also includes a survey of surviving manuscripts from Benevívere. ${ }^{8}$ Lewis E 22 is not among the manuscripts recorded by Pérez and appears to be almost unknown in the literature on the monastery.

6 On this topic, see Markus Schiegg, "Scribes' Voices: The Relevance of Types of Early Medieval Colophons," Studia Neophilologica 88 (2015): 129-46; for a later example with this same formula, see Fernando Villaseñor Sebastián, El Libro Iluminado en Castilla durante la segunda mitad del siglo XV (Segovia: Fundación Instituto Castellano y Leonés de la Lengua, 2009), 236.

7 On the history of Benevívere and its customary, with a complete transcription, see Luis Fernández, La Abadía de Santa María de Benevívere durante la Edad Media: su historia, su regla (Comillas: Universidad Pontificia, 1962). On folios 86-88, the customary outlines when and where parchment could be scraped and books copied, annotated, and bound, restricting the use of the cloister for these activities when it might distract from prayer.

8 Estrella Pérez Rodríguez, Vita Didaci, poema sobre el fundador de Benevívere: Estudio y edición crítica con traducción del poema y de los diplomas relacionados (León: Universidad de León, Secretariado de Publicaciones, 2008); for the list of surviving books and charters docu- 


\section{Westerby: "Didacus" in a Late Twelfth-Century Manuscript}

\section{Provenance Beyond Palencia}

The omission of Lewis E 22 from modern Spanish historiography is no doubt a result of the circumstances in which the manuscript was exported in the middle of the nineteenth century, not long after the monastery's exclaustration in the wake of the Spanish ecclesiastical confiscations. Beginning in the 1830s, in a span of a few decades, all of Benevivere's lands and possessions were dispersed. It was ultimately shuttered in 1843 , and the remainder of its properties sold off that same year, the buildings intentionally demolished to prevent the return of any religious community. ${ }^{9}$ The abbey was depicted as an architectural ruin in a lithograph titled "Ruinas de Benevibere" published in 1861 by Francisco Javier Parcerisa. A scattering of objects from Benevivere are housed today at the Museo Diocesano de Arte in nearby Palencia, including a monumental stone sundial, a sculpted tomb, and various lapidary fragments. ${ }^{10}$

Untraced until now, Lewis $\mathrm{E} 22$ is in fact noted among the possessions of the monastic library in 1785 as one of forty-two codices recorded by Juan Sobreira y Salgado (1746-1805). Among a handful of manuscripts that Sobreira dates to the twelfth century are copies of Augustinian commentaries, including the Commentaries on the Psalms, which Sobreira further identifies as "Liber Enchiridion." ${ }^{11}$ In all likelihood this is a reference to Lewis

menting the early history of the monastery, see 1.2.1, "Fuentes para la historia del monasterio," 44-45.

9 On the history of Benevivere and its exclaustration in the nineteenth century, see Santiago Peral Villafruela, "Magnificencia y barbarie en Benevívere en el segundo tercio del siglo XIX," Publicaciones de la Institución Tello Téllez de Meneses 82-83 (2011-12): 343-94.

10 On the sundial and sarcophagus, see Gerardo Boto Varela and José Luis Hernando Garrido, "Canónigos regulares, hospitalarios y santiaguistas: claustros para la fraternidad y la pobreza," in J. Yarza Luaces and G. Boto Varela, eds., Claustros románicos hispanos (León: Edilesa, 2003), 153-79 at 162-63 and 168.

11 Juan Sobreira's notes documenting his visit to the library at Benevivere in 1785 are titled "Noticia histórica del monasterio de Benevívere y de los códices que se guardan en su archivo," this notebook today in Madrid at the Real Academia de la Historia as MS E 166. See Fernández, La Abadía de Santa María de Benevívere, 58-59: "Al primer group, o sea, de carácter teológico, pertenecian ... un comentario de San Agustín super Canticum de letra del s. XII y 
E 22, identified by its two main texts, and shows that the codex was still in the possession of the monastery in the late eighteenth century.

The Englishman William Bragge acquired the manuscript sometime around the middle of the nineteenth century, perhaps while traveling through Spain. ${ }^{12}$ Because Lewis E 22 retains its twelfth-century binding, it probably was not traded on the English antiquarian book market in the 1850s and 1860s, when many manuscripts were routinely rebound in fresh morocco and their historic bindings discarded. ${ }^{13}$ Bragge perhaps acquired Lewis E 22 prior to the 1870 s during his active phase as manuscript collector. ${ }^{14}$ It is not listed among the manuscripts Bragge lent to the landmark 1874 exhibition at the Burlington Fine Arts Club in London; however, Lewis E 22 probably fell outside the scope of this exhibit since it is not illuminated. ${ }^{15}$ We are also fortunate that the codex was not lost along with hundreds of rare books from Bragge's Cervantes library, which he donated to the city of Birmingham in 1874 and which was almost entirely destroyed by fire just a few years later. $^{16}$

Lewis E 22 is first documented in the nineteenth century in the anonymous 1876 sale of Bragge's library, as lot $20 .{ }^{17}$ The description notes the oak boards of its early binding and is the first to mention the Didacus

otro sobre los salmos de la misma época, un Liber Enchiridion." See also Julio González, "La biblioteca del monasterio de Benevivere," Revista de Bibliografía Nacional 3 (1942): 256-59.

12 On Bragge's travels and activity as a collector, see William Stoneman, "The Linked Collections of William Bragge (1823-1884) of Birmingham and Dr. Thomas Shadford Walker (1834-1885) of Liverpool," Manuscript Studies 1, no. 2 (2017): 263-72. Bragge's travels and acquisitions can also be traced across his collection of tobacco paraphernalia published in Bibliotheca Nicotiana: A Catalogue of Books about Tobacco (Birmingham: Privately printed, 1880), where Bragge says in his introduction, p. ii, that this collection "was begun as the recreation of a busy life to a large extent spent in travelling, thus affording special opportunities for collecting."

13 I am grateful to Christopher de Hamel for this suggestion.

14 Stoneman, "The Linked Collections of William Bragge," 264, notes that Bragge was blind later in life and was probably unable to appreciate his collection of rare books and manuscripts from that moment onwards, further implying that Bragge was no longer actively acquiring by the 1870 s.

15 Illuminated Manuscripts Catalogue (London: Burlington Fine Arts Club, 1874).

16 Stoneman, "The Linked Collections of William Bragge," 264.

17 Sotheby, Wilkinson \& Hodge, London, 7 June 1876, lot 20, "Catalogue of a Magnificent Collection of Manuscripts formed by a Gentleman of Consummate Taste \& Judgment." The 


\section{Westerby: "Didacus" in a Late Twelfth-Century Manuscript}

inscription, here attributing the name Didacus to the scribe. ${ }^{18}$ Bernard Quaritch purchased Lewis E 22 in the 1876 sale, and in 1877 it appears in a Quaritch catalogue for the first time, listed among recent purchases and closely following the description published in the Bragge sale. ${ }^{19}$ It was published again by Quaritch in 1886, adding an erroneous identification of its origin as the "Cistercian abbey of Valverde in Old Castile." ${ }^{20}$ A pencil inscription written in English with this same erroneous attribution appears below the early ex libris inscription on folio 181v (fig. 1).

After Lewis E 22 was purchased by Gerald Hart of Montréal and resold in 1890, the manuscript appears again in a Quaritch catalogue in 1893. ${ }^{21}$ Interestingly, the 1893 Quaritch catalogue does not identify Didacus as the name of the scribe, instead simply transcribing the colophon. The 1893 catalogue does give more attention to the early binding, calling it "the oldest example of book-binding in my possession, being not later than the year 1200."22 This early binding probably also appealed to its subsequent owners, first George Dunn of Woolley Hall near Maidenhead (Berkshire), and later John Frederick Lewis of Philadelphia, who purchased the manuscript from Dunn's 1913 sale at Sotheby's in London. ${ }^{23}$ Like the earlier Quaritch catalogues, the 1913 Sotheby's catalogue identifies Didacus as the

first portion is further identified as "the highly important collection of illuminated and other manuscripts formed by an English gentleman."

18 Sotheby, Wilkinson \& Hodge, London, 7 June 1876, lot 20, 5: "at the end is a notice that the Scribe's name was Didacus."

19 Bernard Quaritch, A New Catalogue of Miscellaneous Books, forming a Supplement to those Advertised in the General Catalogue for 1874 (London, January 1877), 1303, no. 13347, listed at $£ 14$, adding: "I cannot discover the modern or native name of Benevivere; it would add to the interest of the book if, with a little trouble, this origin could be traced."

20 Bernard Quaritch, Catalogue of Manuscripts, no. 369 (London: September 1886), no. 35779 .

21 C. F. Libbie \& Co., Boston, MA, 15-19 April 1890, lot 1529 ("Catalogue of the Hart Collection").

22 Bernard Quaritch, A Catalogue of Greek and Latin Classics, no. 154 (London: B. Quaritch, September 1893), 11-12.

23 Sotheby's, London, 13 February 1913, lot 389 (“Catalogue of the Valuable \& Extensive Library formed by George Dunn, Esq. [deceased] Woolley Hall, near Maidenhead”). Two snippets from the 1913 Dunn sale catalogue are pasted inside the rear board of Lewis E 22. 
“original scribe.” Finally, in 1936, the manuscript entered the Free Library of Philadelphia as the gift of Anne Baker Lewis.

\section{The Shadow of Didacus}

Only fragments of twelfth-century architecture and sculpture survive from the early monastery at Benevívere. Among these is an unusual sundial-stele reconstructed from two large fragments. ${ }^{24}$ Snaking around the outer edge of its two roundels in cryptic, nested letters is a long inscription with the names of the aedificator, Didacus, and first abbot, Paschasius. These names are set on a vertical axis along with the date of the founder's death on 5 November. The inscription inverts as it loops around the lower roundel, forcing the reader-viewer to contort the words in one's mind to comprehend the meaning, or perhaps forcing the reader-viewer to bend sideways, as if performing genuflection. ${ }^{25} \mathrm{~A}$ gnomon (no longer extant) that stood perpendicular to the lower roundel would have cast a shadow over the words below, so that "Didacus" was indicated by the gnomon's shadow each day as the sun moved across the sky.

In addition to the lengthy Vita Didaci, the sundial-stele is tangible evidence that the memory of the founder Didacus was central to everyday life at Benevívere. This might be seen within a larger nexus of memory and ritual focused on the name Didacus. This cult of memory is first recorded in the actions of the abbot Paschasius in 1199, setting aside funds for an annual feast in memory of Didacus and an olive oil lamp to stand near the

24 For the sundial and other fragments, see José Luis Hernando Garrido, "San Agustín de Benevívere," in Yarza Luaces and Boto Varela, Claustros románicos hispanos, 168 (with bibliography). The Benevívere sundial, known as an borologium in the twelfth century, has also been called a funerary stele. I here refer to this object as a sundial-stele.

25 By comparison, the performativity of epigraphy in Romanesque church portals has been studied by Calvin Kendall in "Portal Inscriptions as 'Performatives," in his The Allegory of the Church: Romanesque Portals and Their Verse Inscriptions (Toronto: University of Toronto Press, 1998), 92-98. 
main altar of the church, to remain lit day and night. ${ }^{26}$ Also created around 1200 , and thus very nearly contemporary to the sundial-stele, Lewis E 22 and the Didacus inscription can be seen to offer further evidence of the wide extent of innovative memorial strategies at Benevívere that centered on the name Didacus. The addition "Didacus vocavatur a domino benedicatur" ("He was called Didacus, may he be blessed by the lord"), added after the colophon on folio 181v, puts the name Didacus in proximity to Augustine, the author of the two main texts written in the codex and of the monastic rule followed at Benevívere. Beyond the aedificator Didacus, Diego Martínez de Villamayor, this could include those who took the name Didacus to honor the founder of Benevívere-possibly including the scribe of Lewis E 22. ${ }^{27}$

More speculatively, we can imagine Lewis E 22's reader-viewers casting their gaze over Didacus's name on the final folio, performing a recurring pattern not unlike the gnomon's shadow over Didacus's name on the sundial or the labor of the sacristan to keep Didacus's lamp lit day and night. The manuscript was among the first batch of books produced at the monastery in its first decades, copied in the newly established scriptorium that was conducting work within a few years of the founder's death. Recontextualized within the early history of Benevívere, Lewis E 22 offers important evidence for our understanding of a monastery from which very little other evidence remains.

26 Luis Fernández, Colección diplomática de la Abadía de Santa María de Benevivere (Palencia) 1020-1561 (Madrid-Atocha: Escuela Gráfica Salesiana, 1967), doc. no. 33: "Similiter XV dentur sacristae ad opus luminarium ecclesiae et dormitorii ex quibus luminaribus una lampas ardeat de oleo olivarum ante maius altare semper nocte dieque."

27 The practice of monks and conversi taking the name of a superior is known elsewhere in Spain, including at Santa Maria de Ripoll in Catalonia, where the monk Oliba (d. 1065) took his name in honor of the abbot-bishop Oliba (d. 1045); see Màrius Bernadó, Hispania Vetus: Musical-Liturgical Manuscripts from Visigotbic Origins to the Franco-Roman Transition (9th12th Centuries), ed. Susana Zapke (Bilbao: Fundación BBVA, 2007), 348. 